\section{Ordforklaringer}

Ung-HUNT 1: Ungdomsdelen av Helseundersøkelsen i Nord-Trøndelag 1995-97. med 8090 deltakere.

Ung-HUNT 2: Oppfølgingsstudie av de yngste fra Ung-HUNT 1 i 2000-01, med 2400 deltakere.

Spiseproblemer: Ikke-diagnostiske spiseforstyrrelser. Definert ved hjelp av Eating Attitude Test (EAT), med sju spørsmål, der subskalaene er oral kontroll og overopptatthet av mat. I spørreskjemaet som ble brukt i Ung-HUNT, var definisjonen av spiseproblemer uregelmessig måltidsstruktur, unødvendig slanking og/eller kroppsmisnøye.
Myelomatose: Beinmargskreft. Utgår fra plasmaceller som blir ondartede og vokser og sprer seg i beinmargen. Sykdommen viser stor genetisk og biologisk variasjon. De fleste pasientene er over 50 år når de får diagnosen. Vanlige symptomer er smerter pga. ødeleggelse av skjelettet, økt tendens til infeksjoner, anemi og nyresvikt.

PRL-3: Fosfatase for regenererende lever 3. Denne fosfatasen kan fjerne fosfatgrupper på aminosyrene tyrosin, serin og treonin og har vist seg å være assosiert med metastasering i mange solide svulster.

BCL-3: B-cellelymfom gen 3. Medlem av en proteinfamilie som regulerer transkripsjonsfaktorer i NF-k-B-familien. BCL-3 modulerer disse transkripsjonsfaktorenes DNA-bindende aktivitet. BCL-3 finnes stort sett i cellekjernen.

SGK-1: Serum-glukokortikoidinduserende kinase 1. Tilhører en familie av syklisk AMP- og syklisk GMP-avhengige serin/ treoninkinaser. Det er kjent at SGK-1 induseres av blant annet cellulært stress, steroidhormoner og ulike vekstfaktorer.

PAK: p21-aktiverte kinaser. Tilhører serin/ treoninkinasene og er multifunksjonelle proteiner som har vist seg å kunne ha betydning i kreftutvikling.

\title{
Spiseproblemer vanlig hos ungdom
}

\author{
Svært mange norske ungdommer har spiseproblemer. Halvparten \\ av jentene og en tredel av guttene har spise- og vektproblem av ulik \\ alvorlighetsgrad.
}

Sigrid Bjørnelv har i sin avhandling benyttet data fra Ung-HUNT 1 og 2, der 8090 ungdommer i alderen 13-18 år har besvart spørreskjema og i tillegg er blitt veid og målt. Dataene er sammenliknet med data fra Statens helseundersøkelser fra 1966-69, der like mange ungdommer var inkludert. Konklusjonen er at ungdom er blitt tykkere de siste 30 årene - særlig gutter.

- Andelen overvektig ungdom har økt med $60 \%$ i denne perioden, fra $10 \%$ til $17 \%$. Vi fant en klar kjønnsforskjell, der endringen er størst hos guttene. Gjennom-

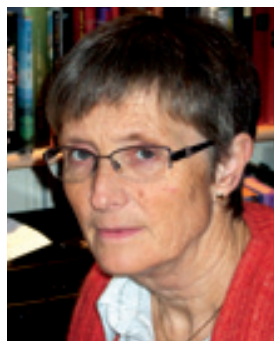

Sigrid Bjørnelv. Foto privat snittlig kroppsmasseindeks (BMI) hos gutter har økt med $0,6 \mathrm{BMI}$-enheter $(1,5-2 \mathrm{~kg})$, sier Bjørnelv.

Blant jentene har ikke gjennomsnittlig BMI økt i denne perioden, men de tynneste er blitt tynnere og de tykkeste er blitt betydelig tykkere. Dette gjelder også for gutter.

Spiseproblemer var vanligere hos jenter enn hos gutter, og Bjørnelv fant en klar sammenheng mellom vekt og type spiseproblem. De som var undervektige, hadde en høyere andel av anorektiske symptomer (oral kontroll), mens de som var overvektige eller fete hadde høyere grad av bulimiske symptomer. Hele $80 \%$ av ungdommene hadde en relativt stabil vekt gjennom hele ungdomstiden.

- Det er viktig å forebygge spise- og vektproblemer hos ungdom. Men grunnlaget for vektproblemer legges tidlig, så det er for sent å starte forebygging i ungdomsskolen, mener Bjørnelv.

Hun disputerte for ph.d.-graden ved Norges teknisk-naturvitenskapelige universitet 18.9. 2009, med avhandlingen Eatingand weight problems in adolescents. The Young-HUNT Study.

\section{Eline Feiring}

eline.feiring@legeforeningen.no Tidsskriftet

\section{Gener med betydning for beinmargskreft}

\author{
Gener som oppreguleres av flere ulike vekstfaktorer fra beinmargs- \\ miljøet og som påvirker ulike prosesser i kreftcellene, kan bli \\ angrepspunkter for nye behandlingsregimer.
}

Hvert år rammes ca. 300 nordmenn av myelomatose (beinmargskreft). Sykdommen kan ikke helbredes, og halvparten av pasientene dør 3-5 år etter diagnose. Unn-Merete Fagerli har funnet frem til gener som kan ha betydning for sykdomsutviklingen.

- Gener som oppreguleres av flere ulike vekstfaktorer kan være «knutepunkt» for ulike prosesser og dermed viktige for sykdomsutviklingen. De kan også være gode angrepspunkter for fremtidig behandling. Ved hjelp av studier i cellelinjer og pasientmateriale fant vi frem til flere gener og proteiner som har betydning for myelomcellenes vekst og migrasjon, forteller Fagerli.

Flere gener ble valgt ut for videre studier. Både $P R L-3$ og $B C L-3$ var overuttrykt hos mange pasienter med myelomatose. Pasienter med høyt uttrykk av $B C L-3$ hadde dessuten dårlig prognose.
Nedregulering av $P R L-3$ og $P A K$ reduserte migrasjonsevnen til myelomceller. $S G K-1$ var bare aktivt i celler som delte seg, og nedregulering av genet reduserte vekst og overlevelse hos cellene.

- Fremtidig behandling må designes slik at det rammer «knutepunkter» for prosesser i kreftcellene og deres interaksjon med mikromiljøet samtidig. Genene vi har studert her kan være mulige angrepspunkter, sier hun.

Fagerli forsvarte avhandlingen $\mathrm{Mul}$ tiple myeloma cells and cytokines from the bone marrow environment; aspects of growth regulation and migration for ph.d.-graden ved Norges teknisk-naturvitenskaplige universitet 17.9. 2009.

\section{Anne Forus}

anneforu@online.no

Tidsskriftet 